FORESTRY

\title{
Performance Assessment of Newly Improved High Yielding Wheat Varieties in the Irrigated Farming Situations of Birbhum District, West Bengal
}

\author{
Prabuddha Ray ${ }^{1 *}$, Subrata Mandal ${ }^{2}$, Sri Sourav Mondal ${ }^{3}$ and Sri Palash Ankure ${ }^{4}$
}

${ }^{1}$ Subject Matter Specialist (Agricultural Extension), Rathindra Krishi Vigyan Kendra, Palli Siksha Bhavana (Institute of Agriculture), Visva-Bharati, Sriniketan, West Bengal, India

${ }^{2}$ Programme Coordinator (Officiating) and Subject Matter Specialist (Agronomy), Rathindra Krishi Vigyan Kendra, Palli Siksha Bhavana (Institute of Agriculture), Visva-Bharati, Sriniketan, West Bengal, India

${ }^{3}$ Subject Matter Specialist (Plant Protection), Rathindra Krishi Vigyan Kendra, Palli Siksha Bhavana (Institute of Agriculture), Visva-Bharati, Sriniketan, West Bengal, India

${ }^{4}$ Programme Assistant (Farm Manager), Rathindra Krishi Vigyan Kendra, Palli Siksha Bhavana (Institute of Agriculture), VisvaBharati, Sriniketan, West Bengal, India

*Corresponding author: prabuddha_ray1@rediffmail.com (ORCID ID: 0000-0001-9283-275X)

Paper No. 806

Received: $12-06-2019$

Revised: $18-10-2019$

Accepted: 30-11-2019

\begin{abstract}
Wheat is one of the potential crops in Birbhum District from a platter of crops having utility in a crop diversification programme. As crop diversification is one of the major thrust areas of the Rathindra Krishi Vigyan Kendra, the Kendra has taken up the crop diversification programme with newly improved High Yielding (HY) wheat varieties through its Front Line Demonstration (FLD) Programmes for the last couple of years. In Birbhum the average yield of Wheat stood at $2950.20 \mathrm{~kg}$. / ha in 2015-16. This figure shows that there is a lot of scope in improvement in productivity as concerned. So, the main objectives of these demonstration programmes of the Rathindra Krishi Vigyan Kendra were to show the farmers the modern methods of wheat cultivation using resource conservatory technologies thus increasing the production, productivity, net returns and B: C ratio. The results from the FLD Programmes showed us that the highest ever yield was achieved by the newly improved HYV HD - 2824 in the year of 2014-15 with an average yield of $4056.00 \mathrm{kgs}$. / ha with an yield increase of 21.92 per cent over the local check variety Sonalika (yield - $3330.00 \mathrm{kgs}$. / ha) and with a B : C Ratio of 2.32. However, the highest yield increase over the local Check Variety Sonalika, Net Income and as well as B: C Ratio were highest in the case of Variety PBW - 343 with a Yield increase of 27.50 per cent, an average Net Income of ₹ 32,049.00 / ha and B: C Ratio of 2.39 in the year of 2016-17. The studies conducted on the performances of the FLDs organized by the Rathindra Krishi Vigyan Kendra on newly improved Wheat Varieties safely point out that HD - 2824 and PBW - 343 are the two HYVs of Wheat which can meet up the growing demands of Wheat Varieties with improved yield and as well as increased income potential for irrigated situations of Birbhum District.
\end{abstract}

Highlights

0 The present study finds out that cultivation of two newly improved HYV Wheat Varieties viz. HD - 2824 and PBW - 343 have the potential to meet up the growing demands of Wheat Varieties with improved yield and as well as increased income potential suitable for irrigated farming situations of Birbhum District of West Bengal.

Keywords: Wheat Variety, Newly improved High Yielding Varieties, Yield, Net Income, B: C Ratio, HD - 2824 and PBW - 343 
Wheat is one of the prime cereal crops in the world. Wheat and Wheat based derivates are among the primary sources of the staple foods all over the world. In India also, Wheat is one of the two dominating Cereals with the other being Paddy. Traditionally, Wheat cultivation in India has been dominated by the northern region of India. Wheat has played a very vital role in stabilizing the food grain production in the country over the past decades beginning from the "Green Revolution" in the late sixties.

However, one of the main problems associated with Wheat cultivation in India is the spacio-temporal stagnation of its production (Pushpa et al. 2017). Though, the northern Plains of Punjab, Haryana and Western Uttar Pradesh in India have been prolific wheat producers producing nearly 70 per cent of the total Indian production, but still there are huge untapped potential for its production in other States like West Bengal, Kerala, Assam, Odisha and Andhra Pradesh with the provision of better irrigation facilities in these areas (Harwinder et al. 2016). There is a tremendous scope for area, production and productivity expansion in Wheat in West Bengal and also Birbhum District as a part of the state of West Bengal which will be clear from the table 1 .

The table 1 shows us that the area, production and productivity of Wheat in West Bengal is far behind from the top three Wheat producing States of India viz. Uttar Pradesh, Madhya Pradesh and Punjab and also considerably below the national

Table 1: Comparative Status of Wheat Cultivation among Various States of West Bengal as regards to Area, Production and Productivity

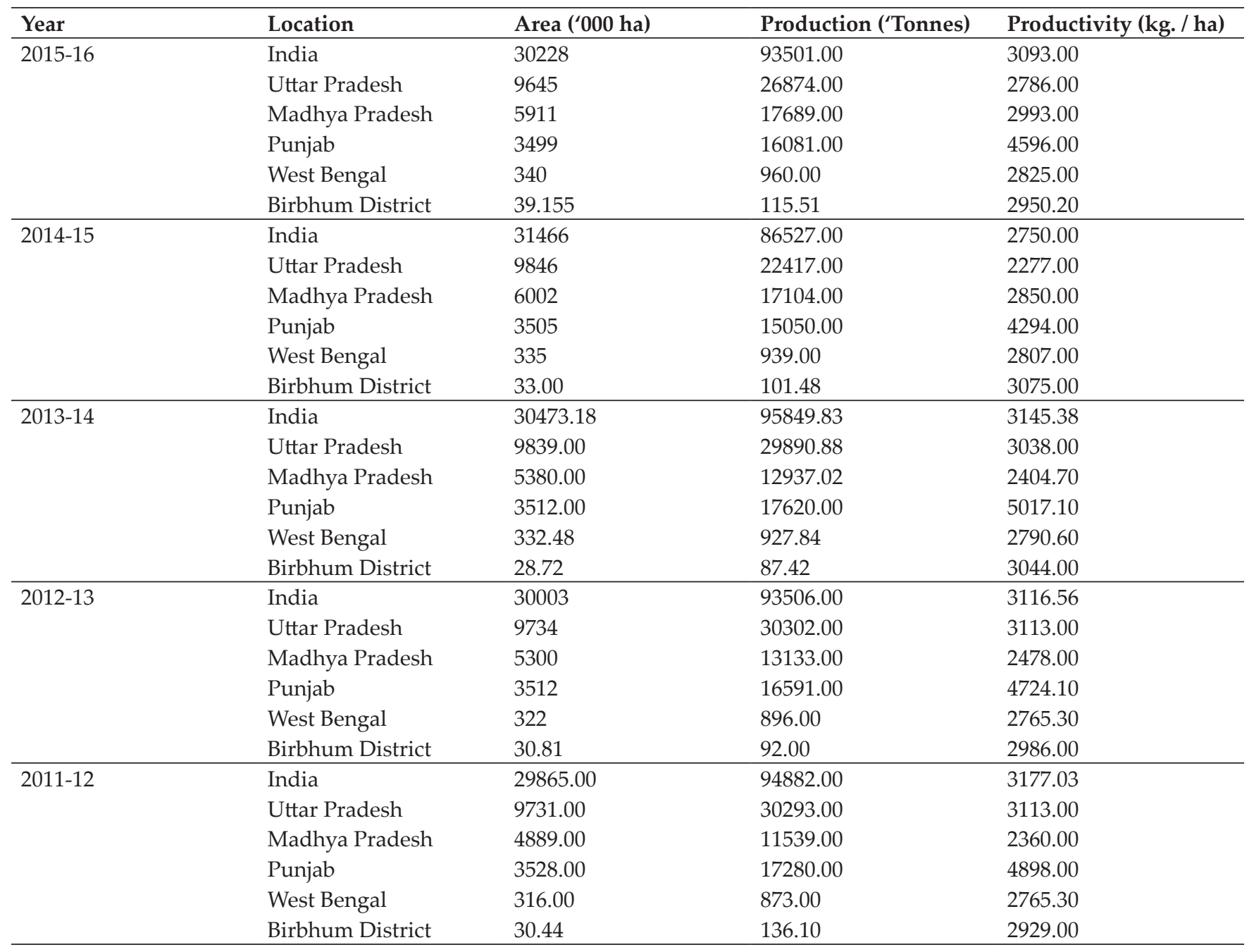

Source: AGRICULTURE - Statistical Year Book India 2017, Ministry of Statistics and Programme Implementation, Govt. of India.

Internet Source: http://mospi.nic.in/statistical-year-book-india/2017 
parameters. However, the productivity of Wheat in West Bengal is not far below the National average, truly speaking it is more or less within a reachable distance to achieve the National Average Productivity. At the same time, it is important to note that the productivity of Wheat is consistently higher in Birbhum District of the State of West Bengal than the State Average and the Birbhum District Wheat productivity is nearer to that of the National Average.

The above mentioned fact points out the potential of Wheat in Birbhum District from a platter of crops having utility in a crop diversification programme. Utilizing this potentiality of Wheat in the irrigated farming situations of Birbhum District, the Rathindra Krishi Vigyan Kendra has taken up the crop diversification programme with newly improved High Yielding (HY) wheat varieties through its Front Line Demonstration (FLD) Programmes for the last couple of years as crop diversification is one of the major thrust areas of the Kendra. In Birbhum the average yield of Wheat stood at $2950.20 \mathrm{~kg}$. / ha in 2015-16. This figure shows that there is a lot of scope in improvement in productivity as concerned. So, the main objectives of these demonstration programmes of the Rathindra Krishi Vigyan Kendra were to show the farmers the modern methods of wheat cultivation using resource conservatory technologies thus increasing the production, productivity, net returns and B: C ratio.

\section{Objective of the Study}

1. To perform a comparative assessment of performances of different High Yielding Wheat Varieties demonstrated by Rathindra Krishi Vigyan Kendra from the year of 2013-14 to 2016 - 17 regarding Bio-Physical attributes viz. Average Numbers of Tillers / Hill and Grains / Ear;

2. To have a comparative assessment of performances of different High Yielding Wheat Varieties demonstrated by Rathindra Krishi Vigyan Kendra from the year of 201314 to 2016 - 17regarding the Yield (Quintal/ ha) and Percentage Increase of Yield over the Local Check Variety; and

3. To perform a comparative assessment of performances of different High Yielding
Wheat Varieties demonstrated by Rathindra Krishi Vigyan Kendra from the year of 201314 to 2016 - 17 regarding the Economics of Production viz. Gross Cost, Gross Return, Net Return and B: C Ratio with the frame of reference that of the Local Check Variety.

\section{Methodology}

(A) The High Yielding Wheat Demonstration Programmes organized by the Rathindra Krishi Vigyan Kendra, Palli Siksha Bhavana, Visva-Bharati in the years of 2013-14, 2014$15,2015-16$ and 2016-17 are the time frame of the present study and selected plots of the Partner-Farmers of the aforesaid FLD Programme on Wheat throughout the District of Birbhum were spacio-frame of study.

(B) The High Yielding Varieties of Wheat under the present Study were HD 2824 and PBW 343 and the Local Check Variety was Sonalika.

(C) The performances of different High Yielding Wheat Varieties regarding Bio-Physical attributes were measured through Average Numbers of Tillers / Hill and Grains / Ear of the Variety concerned.

(D) The performances of different High Yielding Wheat Varieties regarding the productivity of the individual Variety were measured through the Average Yield (Quintal / ha) and Average Percentage Increase of Yield over the Local Check Variety.

(E) The performances of different High Yielding Wheat Varieties as far as the Economics of Production was concerned were measured through the Variety wise Average Gross Cost (₹), Gross Return (₹), Net Return (₹) and B: C Ratio.

(F) Economics of Wheat Cultivation Calculation: The cost of cultivation of Wheat was estimated under various cost concepts as below:

Cost $\mathrm{A}_{1}=$ Value of hired human labour + Value of hired bullock labour + Value of owned bullock labour + Value of hired machine labour + Value of owned machine labour + Value of seed (both farm produced and purchase) + Value of insecticide and pesticides + Value of manure (owned and 
purchased) + Value of fertilizer + Depreciation on implements and farm buildings + Irrigation charges + Land revenue and other taxes + Value of Interest of working capital + Miscellaneous expenses (artisans etc.).

Cost $A_{2}=$ Cost $A_{1}+$ Rent paid for leased in land

Cost $\mathrm{B}_{1}=$ Cost $\mathrm{A}_{2}+$ Interest on value of own fixed capital assets (excluding land)

Cost $\mathrm{B}_{2}=$ Cost $\mathrm{B}_{1}+$ Rental value of owned land and rent paid for leased- in land.

Cost $\mathrm{C}_{1}=$ Cost $\mathrm{B}_{1}+$ Imputed value of family labour

Cost $C_{2}=$ Cost $B_{2}+$ Imputed value of family labour

Cost $\mathrm{C}_{3}=$ Cost $\mathrm{C}_{2}+$ Value of management input at $10 \%$ of Cost $C_{2}$ (As managerial cost) (Source: - http://eands.dacnet.nic.in).

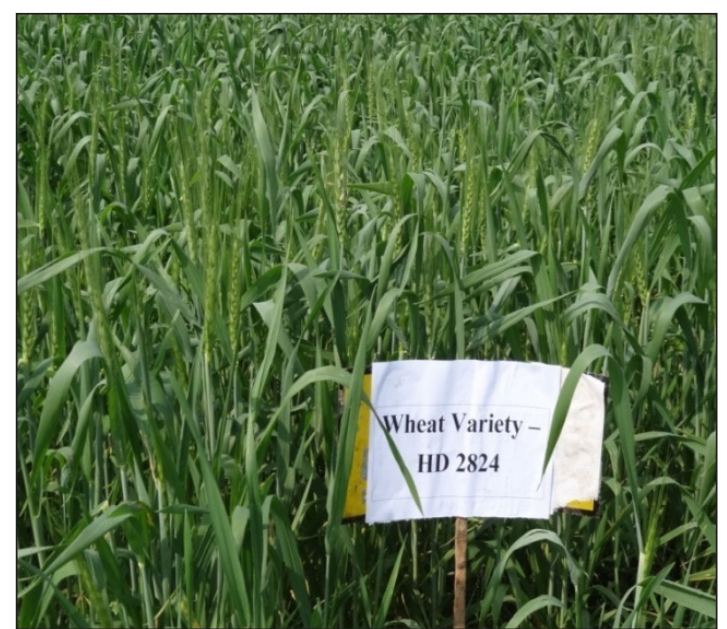

Profitability Aspects Calculation: For the estimation of profitability, the following income measures were used. a) Net Income $=$ Gross Income - Cost $C_{3}$ (Gross Cost $)$ and $b)$ B: $C$ ratio $($ Benefit cost ratio $)=$ Gross Income / Gross Costs.

The cost concepts were used for estimation of wheat cultivation was adopted by Directorate of Economics and Statistics, Department of Agriculture and Cooperation, and Commission for Agricultural Cost and Price, Ministry of Agriculture and Farmers' Welfare, Govt. of India. The gross income, net income and Benefit: Cost (B: C) Ratio were also worked out using different profitability concepts (Ahirwar et al. 2015 and Rathode, 2016). The collected data were processed to work out the various costs and profitability and yield components and bio-physical attributes of different Varieties of wheat under Front Line Demonstration Programmes organized by the Rathindra Krishi Vigyan Kendra from 2013-14 to 2016-17 in the Birbhum District in West Bengal State.

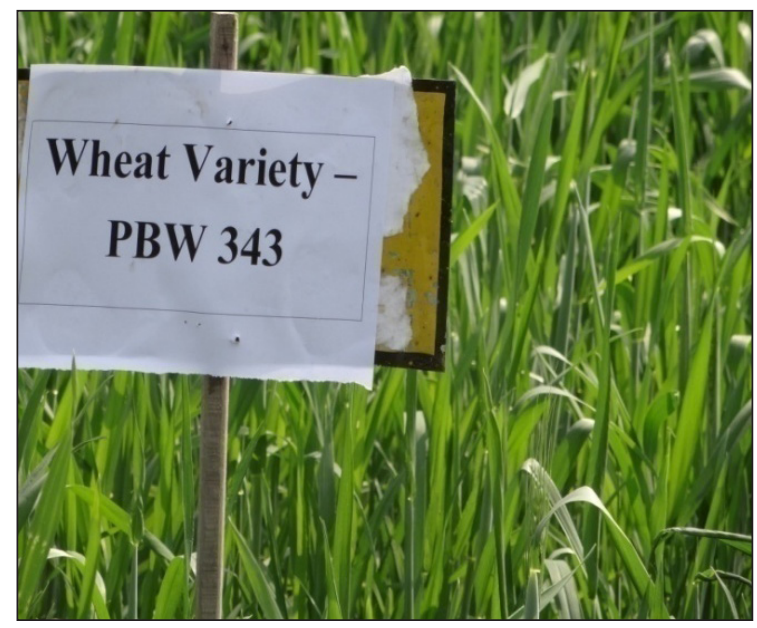

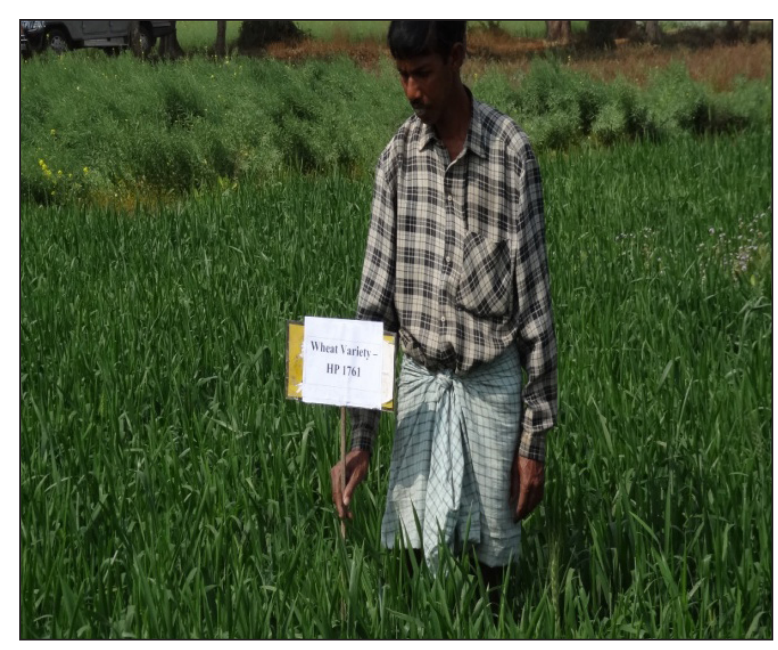

Fig. 1: Front Line Demonstrations on Newly Improved HYV Wheat Varieties organized by Rathindra KVK, Birbhum 
Performance Assessment of Newly Improved High Yielding Wheat Varieties in the Irrigated...

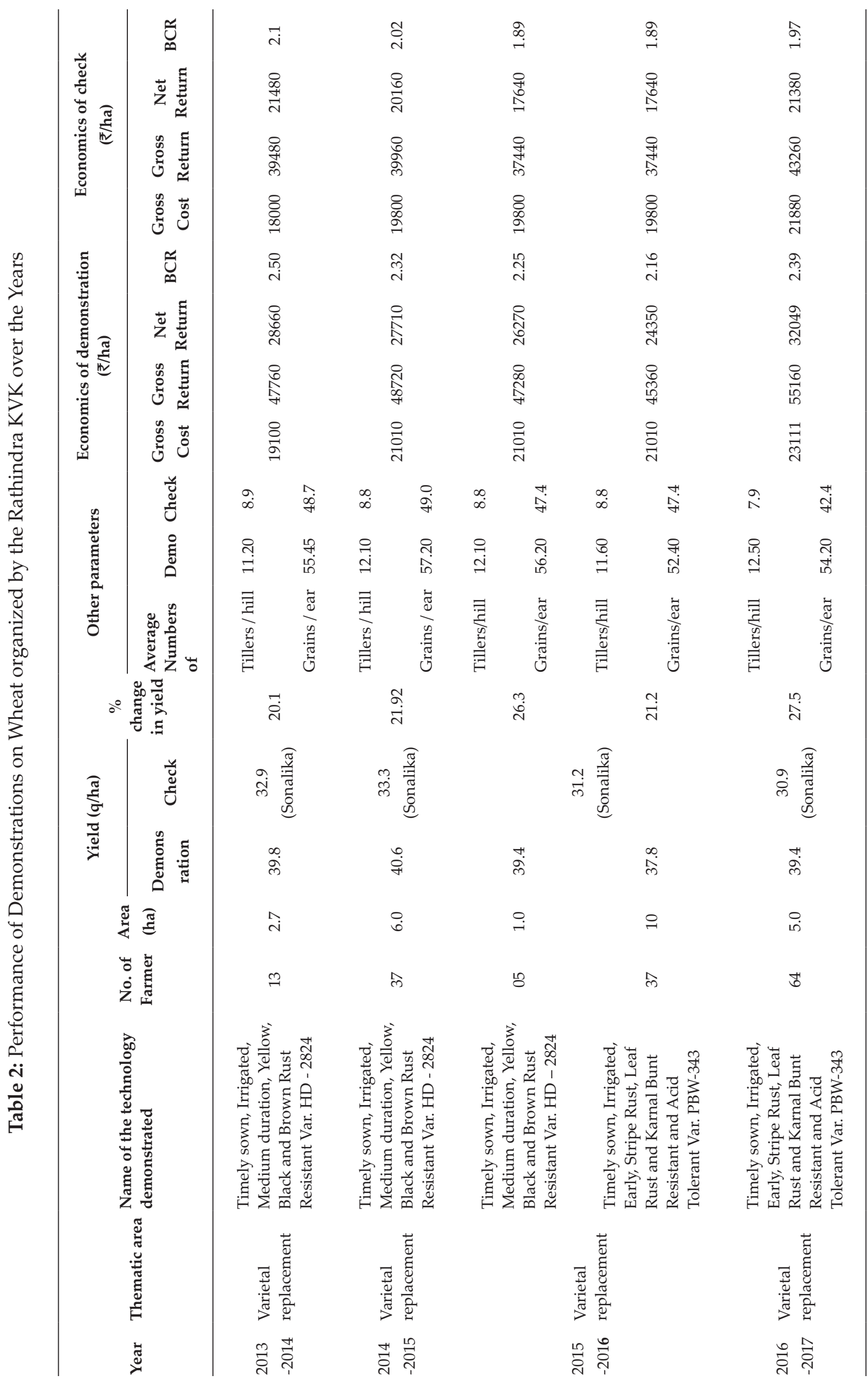




\section{Findings}

The results of the Front Line Demonstration (FLD) Programmes organized by the Rathindra Krishi Vigyan Kendra, Palli Siksha Bhavana (Institute of Agriculture), Visva-Bharati is depicted in following Table 2. As far as Bio-Physical Attributes of the different High Yielding Wheat Varieties are concerned, the Table 2 showed us that the Variety PBW - 343 gave the highest average numbers of Tillers / Hill which stood at 12.50 in the year 2016-17 and the Variety HD 2824 gave the highest average numbers of Grains / Ear which stood at 57.20 in the year of $2014-15$.

The results from the FLD Programmes showed us that the highest ever yield was achieved by the newly improved HYV HD - 2824 in the year of 2014-15 with an average yield of $4056.00 \mathrm{kgs}$. / ha with an yield increase of 21.92 per cent over the local check variety Sonalika (yield - $3330.00 \mathrm{kgs}$./ ha) and with a B : C Ratio of 2.32. However the highest yield increase over the local Check Variety Sonalika, Net Returns and as well as B: C Ratio were highest in the case of Variety PBW - 343 with a Yield increase of 27.50 per cent, an average Net Returns of ₹ 32,049.00 / ha and B: C Ratio of 2.39 in the year of 2016-17.

\section{CONCLUSION}

The results from the FLD Programmes on High Yielding Wheat varieties organized by the Rathindra Krishi Vigyan Kendra showed us that the highest ever yield was achieved by the newly improved HYV HD - 2824 in the year of 2014-15 with an average yield of $4056.00 \mathrm{kgs}$. / ha with an yield increase of 21.92 per cent over the local check variety
Sonalika (yield - $3330.00 \mathrm{kgs}$. / ha) and with a B : $\mathrm{C}$ Ratio of 2.32. However the highest yield increase over the local Check Variety Sonalika, Net Income and as well as B: C Ratio were highest in the case of Variety PBW - 343 with a Yield increase of 27.50 per cent, an average Net Income of Rs. 32,049.00 / ha and B: C Ratio of 2.39 in the year of 2016-17. The studies conducted on the performances of the FLDs organized by the Rathindra Krishi Vigyan Kendra on newly improved Wheat Varieties safely point out that HD - 2824 and PBW - 343 are the two HYVs of Wheat which can meet up the growing demands of Wheat Varieties with improved yield and as well as increased income potential for irrigated situations of Birbhum District of West Bengal.

\section{REFERENCES}

Ahirwar, R.F., Verma, A.K. and Shekhawat, L.S. 2015. Cost and income structure of wheat cultivation in Vindhyan Plateau of Madhya Pradesh, Economic Affairs, 60(1): 83 -88.

Harwinder, K., Hari, R., Rajeev, S. and Harinderjeet, K. 2016. Productivity, agronomic efficiency and quality of bread wheat [Triticum aestivum (L.)] cultivars in relation to nitrogen, International Journal of Agriculture, Environment and Biotechnology, 9(1): 101 - 106.

Pushpa, Srivastava, S.K. and Agarwal, P.K. 2017. Comparative Study on Cost of Cultivation and Economic Returns from Major Crops in Eastern Region of Uttar Pradesh, International Journal of Agriculture, Environment and Biotechnology, 10(3): 387 - 399.

Rathode, K.S. 2016. Economic Analysis of Wheat Production under Different Technological Status of Farms in Khargone District of Madhya Pradesh, Unpublished M. Sc. Thesis, Department of Agricultural Economics and Farm Management, R.A.K. College of Agriculture, Sehore, Madhya Pradesh under Rajmata Vijayaraje Scindia Krishi Vishwa Vidyalaya, Gwalior, Madhya Pradesh, pp. 92. 